\title{
Integrated Structural Analysis of Fractured Basement Reservoir in the South Assam Shelf, India
}

\author{
SHARAD KUMAR MISHRA*, JYOTISH PHUKON, PRANJAL BHOKTIARI and A RAHAMAN \\ Oil \& Natural Gas Corporation Ltd., Jorhat, Assam, India
}

(Received on 15 May 2016; Accepted on 25 June 2016)

\begin{abstract}
Hydrocarbon potential of fractured basement in South Assam shelf has a complex geological history related to episodic evolution of the basin. In the complex tectonic evolution processes from passive margin to active margin, Precambrian Basement has experienced severe fracturing up to deep level. In the highly fractured Basement, where overlying sedimentary column is thicker with the presence of other favourable components of entrapment model, chances of hydrocarbon success is high. The Borholla Field in the north eastern edge of the study area is fully developed for its hydrocarbon commerciality from Basement in last three decades while recent oil find within fractured Basement in southern part in Khoraghat area has also opened up rest of the Basin for Basement exploration. Application of conventional seismic methods for mapping of natural fracture distribution cannot be conducted directly due to dimension of fracture lying below the seismic resolution (sub-seismic). This paper presents an integrated structural analysis of the prospectivity of basement exploration in the study area.
\end{abstract}

Keywords: Coherence; Edge Detect; Horizon Slice; Seismic Attributes; Isochronopach

\section{Introduction}

South Assam Shelf (SAS) is a prolific producer of Hydrocarbon from various pays (Paleogene to Neogene). The commercial discovery of oil from fractured Basement in this area was established during early seventies in Borholla Field. Recent finding of oil in the fractured Basement in Khoraghat area in the far south of earlier discovered Borholla field has propelled to revisit the prospectivity of fractured Basement in the rest of the area with existing $G \& G$ data.

Basement is an unconventional reservoir. It is very complex to characterize the locales of interest within Basement. Hydrocarbon accumulations in fractured Basement are generally seen in the fault zones and associated interconnected networks of fractures. Mapping of fracture distribution in the Basement is done using Seismic data with different indirect techniques like azimuthal velocity/amplitude variation analysis in the strike of fracture direction and estimating the splitting of $S$ wave through anomalous fractured Zone. Different seismic attributes such as coherence, curvature, edgedetect and dip azimuth are also helpful in evaluating fractured basement. To understand the regional setup of the basin and temporal changes in stress field distribution in time and space domain from Paleogene to Neogene sedimentary deposition, various seismic attribute maps and Iso-chronopach maps of different formations using mega merged PSTM seismic data were used.

\section{Geological Setting of the Area}

The study area South Assam Shelf (SAS) falls in the southern part of Assam shelf, which is basically a foredeep basin and located at the tri-junction of Indian shield, Himalayan frontal fold belt and Assam and Arakan Yoma Fold Belt*1. It is located in the south of Brahmaputra river (Fig. 1) and bounded by Mikir hills in the west. The NE-SW trending mobile Naga Schuppen belt makes its eastern boundary. In its north west, Eastern Himalayan frontal thrust belt is oriented in the east west direction. East west trending Jorhat fault separates this study area from the North Assam

\footnotetext{
*Author for Correspondence: E-mail: mishrasarad75@gmail.com
} 


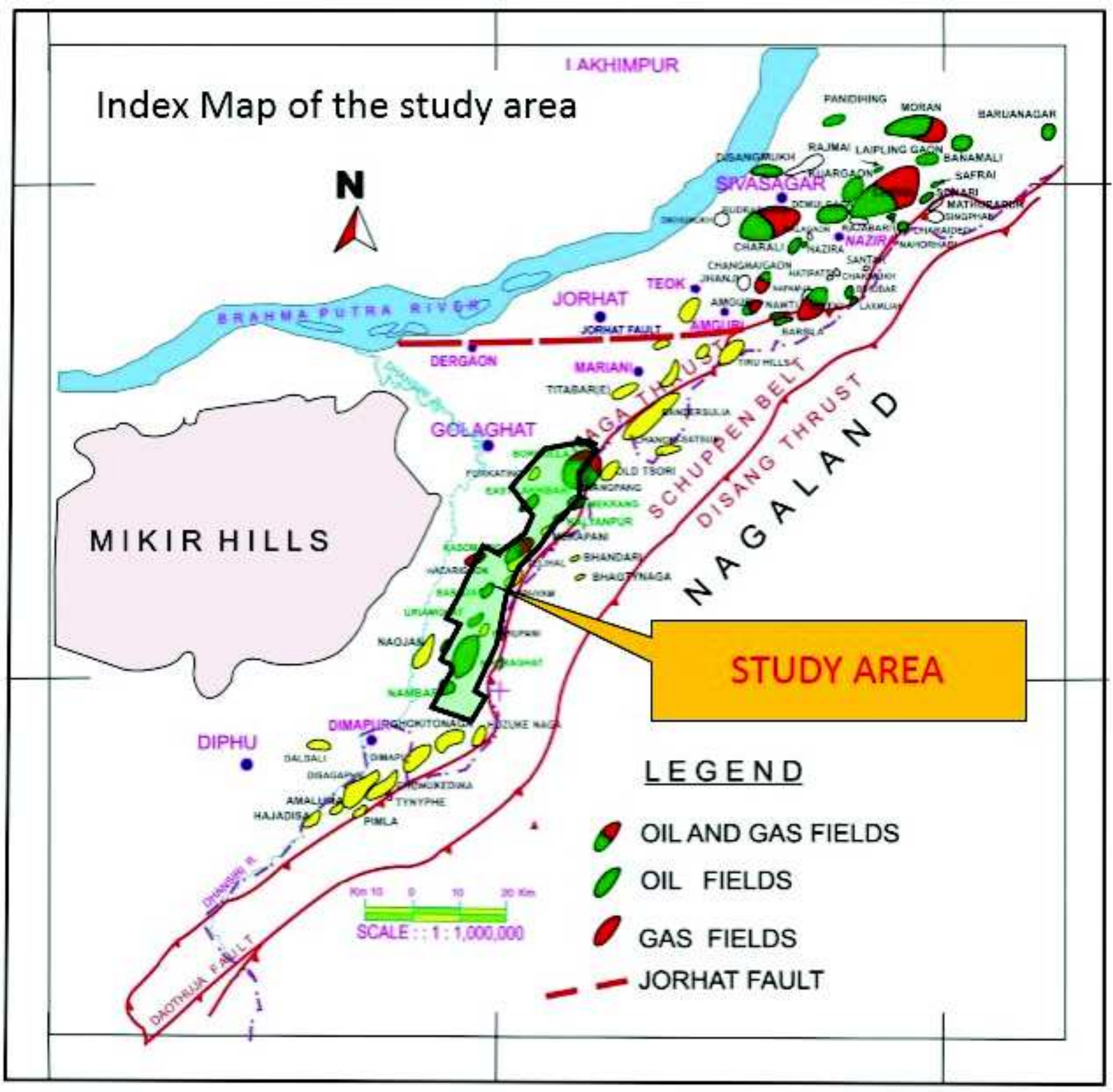

Fig. 1: Index map of the study area

Shelf.

The basin evolved through gradual sequences of rifting of Indian plate followed by drifting and finally collision of Indian plate with Eurasian plate occurred. During the Rifting phases of the Indian plate from super continent "Pangaea" in the late Palaeozoic era to early Mesozoic era evolved several narrow grabens parallel to the eastern plate boundary, where thicker Gondwanic sediments of late Permian to early cretaceous period were deposited during post rifting and at courses of drifting phase ${ }^{* * 2}$. In the Early Eocene period as sea transgressed over shelf areas, passive margin sedimentation started. Till the end of Oligocene, passive margin sedimentation continued. In the earliest part of Miocene period, hard continentcontinent collision of Indian plate with Burmese plate resulted in generation of the foredeep basin followed by active margin sedimentation. This poly-tectonic phases of basin evolution created very complex fault system in the study area. 
Rifting of Indian craton from rest of the Gondwana super continent created a series of horst graben and their bounding fault system in extensional regime. Graben created during rifting phase were filled by late Permian to early Mesozoic Syn-rift sediments, in late Mesozoic time, post-rift sedimentation peneplained these grabens, while horst blocks were exposed for long duration thereby subjecting to sub areal erosion. The passive margin sedimentation initially took place in undisturbed photic warm water environment. A new set of adjustment faults were created in the basinal side to adjust and accommodate the sediment overburden apart from faults created during rifting. The sea gradually receded in the late Oligocene period. The end of the Oligocene marked a major regional unconformity in the area coupled with basinal tilt towards east, which had triggered the most of the south western shelf part vulnerably exposed for its sub areal erosion. Early Miocene period witnessed the evolution of foredeep basin due to hard collision of Indian Plate with Burmese Plate. The eastern compression along with foredeep sedimentation followed by northern compression created a new set of very complex fault mechanism in the late Miocene/Pliocene time. This younger tectonics has re-initiated most of the early set of faults. The same has also created large volume of inter connected fractures at the Basement level, where shock absorbing overburden sediments were thinner.

\section{Methodology and Case Study}

The current study has been carried out utilizing mega merged 3D PSTM reprocessed data of 1000 square $\mathrm{km}$ having a dominant frequency of about $20-30 \mathrm{~Hz}$ at deeper level and $30-40 \mathrm{~Hz}$ at shallower level. To understand the evolution of the basin from Paleogene to Neogene sequences in the study area, seismic data was calibrated with few wells. Synthetic seismograms were generated and different markers were mapped regionally. The deeper marker Sylhet top and younger marker Tipam top are very good reflectors, while mapping of Basement top and Kopili tops are very challenging. Kopili top is a seismically transparent as impedance contrast between Barail bottom facies to upper Kopili facies is very poor. The reflection from Basement top is sometimes ambiguous to differentiate in the case of presence of lower Gondwana unit and basaltic traps, as both are very good reflectors.

\section{Discussions}

\section{Genetic Model of the Pre Foredeep and Post Fore Deep Basin}

The South Assam Shelf area is a south east dipping basin at the basement level on present date. Time relief map on the top of basement (Fig. 2(A)) shows the western part at shallower and eastern part at deeper level. Several ridges/promontories like features bounded by major longitudinal faults in either side due NNE to SSW are present and can be seen vividly on the edge detect attribute in Fig. 2(B). Similar geological features are present at the top of Sylhet and Kopili levels, (Fig. 3(A) and 4(A)), but at younger levels they gradually become gentler. The edge detect attributes (Fig. 2(B), 3(B) and 4(B)) at the Basement top, Sylhet top and Kopili top levels show presence of these longitudinal faults.

The Isochronopach map between Basement top to Sylhet top (Fig. 5(A)) shows that the pach thickness is increasing towards the western side in a defined geometrical pattern. These prominent lows with more pach thickness are Gondwanic grabens, trending north-east to south-west and ENE to WSW in Lakhibari and Furkating area, approximately in east west direction in Gamariguri and Merapani area, while they are clearly in north south direction in west of Khoraghat \& Nambar area. Basically this pach includes Gondwanic sediments, trap flows (at few places in Lakhibari and Merapani area) along with sediments of Tura Formation (average thickness 10 to $15 \mathrm{~m}$ ) and Sylhet formation (average thickness 60 to $90 \mathrm{~m}$ ). These narrow elongated Gondwanic grabens were generated during the late Permian to earliest Triassic period, i.e. during the rifting of Indian Plate from Australian \& Antarctic Plate at the eastern plate boundary. During the initiation of rifting phase, when Indian plate was attached with Antarctic and Australian plates, sedimentation in these grabens were fluvial in nature.In the latter phases during the drifting of Indian plate after detachment from Australian Plate, sedimentation might have taken place in more humid/ marshy environment with brackish water dominance. The log motif of well A-1 in Barpathar area, where total $337 \mathrm{~m}$ thickness of Gondwanic section was encountered, reveals that the lower part of Gondwanic sediments are mostly medium to coarse sands with a few representation of cobbles/pebbles, while the upper 


\section{Generalized Stratigraphy of the Study Area}

The generalized stratigraphy of the study area is as follows:

\begin{tabular}{|c|c|c|c|c|}
\hline Age & Group & $\begin{array}{l}\text { Member } \\
\text { (Formation) }\end{array}$ & $\begin{array}{c}\text { Average } \\
\text { Thickness }(\mathrm{m})\end{array}$ & Lithology \\
\hline Recent & Alluvium & $\begin{array}{l}\text { Newer \& Older - } \\
\text { Alluvium }\end{array}$ & $200-250$ & $\begin{array}{l}\text { Unconsolidated sediments Sands/grits - Pebbly sands \& } \\
\text { Clay }\end{array}$ \\
\hline $\begin{array}{l}\text { Pliocene To } \\
\text { Pleistocene. }\end{array}$ & Moran & DhekiajuliNamsang & $200-150$ & $\begin{array}{l}\text { Unconsolidated Boulders-pebble-gritty Sands - Coarse Sand } \\
\text { / Sands/Sandstone/Clay/Claystone \& Lignite }\end{array}$ \\
\hline $\begin{array}{l}\text { Middle-Late } \\
\text { Miocene to Early } \\
\text { Pliocene }\end{array}$ & Tipam & $\begin{array}{l}\text { Upper S.St } \\
\text { Girujan Clay } \\
\text { Tipam S.St. }\end{array}$ & $500-700$ & $\begin{array}{l}\text { Unconsolidated \& poorly sorted Sandstone with minor } \\
\text { clay/silty clay } \\
\text { Variegated mottled sticky clay } \\
\text { Monotonous Sandstone with minor Clay/Claystone } \\
\text { intercalation }\end{array}$ \\
\hline $\begin{array}{l}\text { Early-Middle } \\
\text { Miocene }\end{array}$ & Surma & Bokabil Fm & $350-450$ & $\begin{array}{l}\text { Shale and Siltstone becomes sandy toward top and grades } \\
\text { to Tipam }\end{array}$ \\
\hline Oligocene. & Barail & $\begin{array}{l}\text { Demualgaon \&Disangmukh } \\
\text { (Undifferentiated) }\end{array}$ & h $200-400$ & $\begin{array}{l}\text { Sandstone/Siltstone with minor shale. Thickness depends } \\
\text { on the degree of erosional effect at the end of Barail } \\
\text { sedimentation }\end{array}$ \\
\hline \multirow[t]{2}{*}{$\begin{array}{l}\text { Late Eocene } \\
\text { Mid. Eocene. }\end{array}$} & \multirow[t]{2}{*}{ Jaintia } & $\begin{array}{l}\text { Kopili } \approx \text { Amguri member } \\
\& \text { Charali member } \\
\text { (Undifferentiated) }\end{array}$ & $250-300$ & $\begin{array}{l}\text { Shale with bands of Sandstone/Siltstone with minor } \\
\text { L.st bands at bottom part }\end{array}$ \\
\hline & & Sylhet & $65-80$ & Limestone with minor shale and Sandstone \\
\hline \multicolumn{2}{|c|}{ Palaeocene. to Eocene } & Tura & $5-12$ & $\begin{array}{l}\text { Sandstone, Siltstone } \& \text { shaleOccasionally with coal seams } \\
\text { at the top part }\end{array}$ \\
\hline \multirow[t]{2}{*}{$\begin{array}{l}\text { Permian to } \\
\text { Early. Cretaceous }\end{array}$} & Trap & $\begin{array}{l}\text { Volcanic Rock } \\
\text { (Intermediate Igneous rock) }\end{array}$ & $40-60$ & Basalt / hyperbasal rock \\
\hline & Gondwana & $\begin{array}{l}\text { Upper GondwanaLower } \\
\text { Gondwana }\end{array}$ & 175 & $\begin{array}{l}\text { Lower part is Mainly Sandstone with Shale alternations. } \\
\text { At places Basalt overlies these sediments }\end{array}$ \\
\hline Pre - Cambrian & Basement & & & Granitic Basement \\
\hline
\end{tabular}

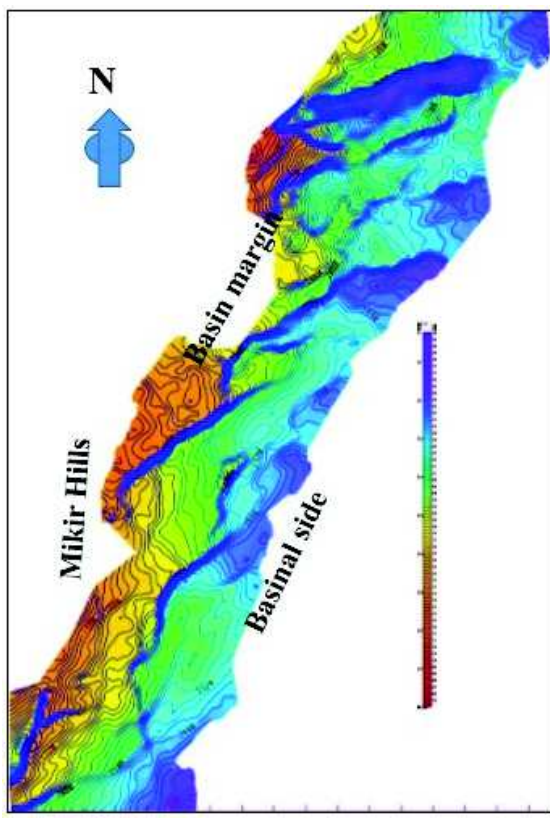

Fig. 2: (A) The relief map on top of Basement top showing its struc-tural pattern

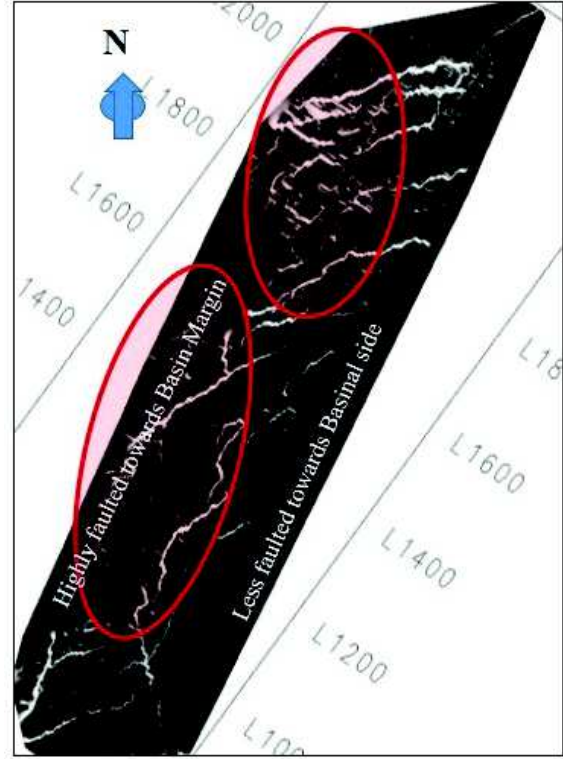

Fig. 2: (B) Edge detect attribute on the top of Basement, showing regional fault pattern present on the Basement top 


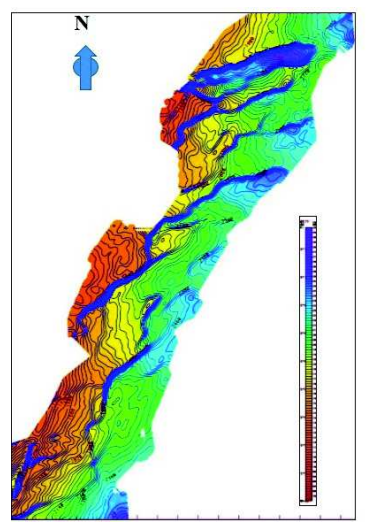

Fig. 3: (A) Regional time relief on the top of Sylhet Formation

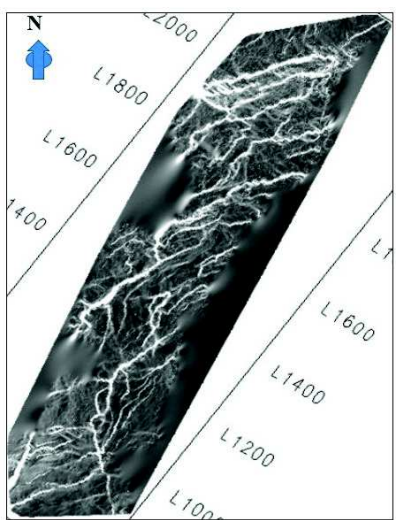

Fig. 3: (B) Edge detect attribute showing regional fault trends present on Sylhet top
Gondwanic sediments are highly Shaly (carbonaceous) in nature with few streaks of medium to coarser sands. The presence of Pyrites crystals in carbonaceous shale dominated upper Gondwanic section corroborates the humid brackish water lacustrine to lagoonalas depositional environment (Fig. 7). The lower Gondwanic sediments are coarser clastic in nature,

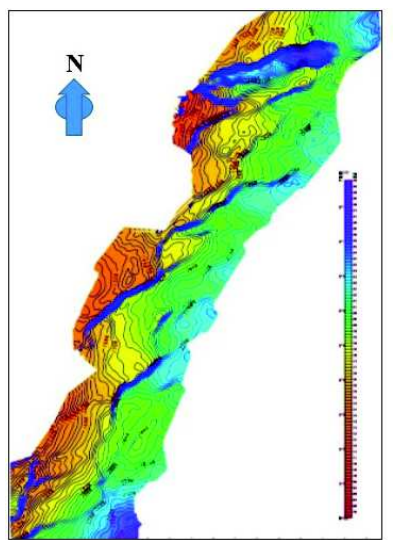

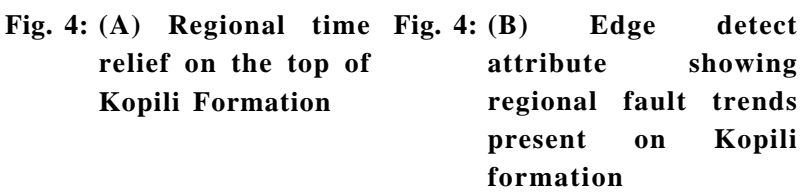

while upper Gondwanic sediments are finer and shale dominated. This makes the strong impedance contrast between lower \& upper Gondwanic unit (Fig. 6(A)) as appears in seismic section.

The Isochronopach between Sylhet top to Kopili top (Fig. 5(B)), represents the Kopili Formation thickness. Kopili Formation thickness varies from

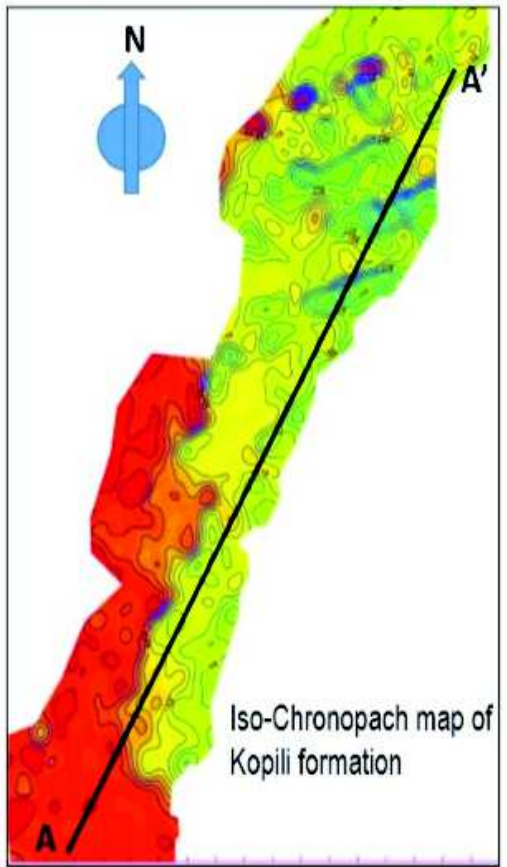

Fig. 5: (A) Iso-chronopach map between Basement top to Sylhet top

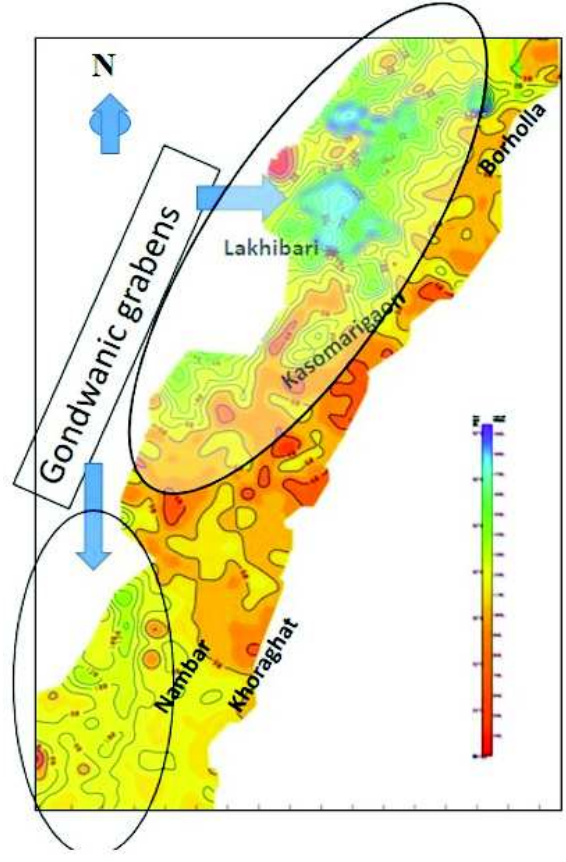

Fig. 5: (B-1) An interpreted seismic section $A-A^{\prime}$ in the $S W$ to $N E$ direction represents the increasing thickness of Kopili formation
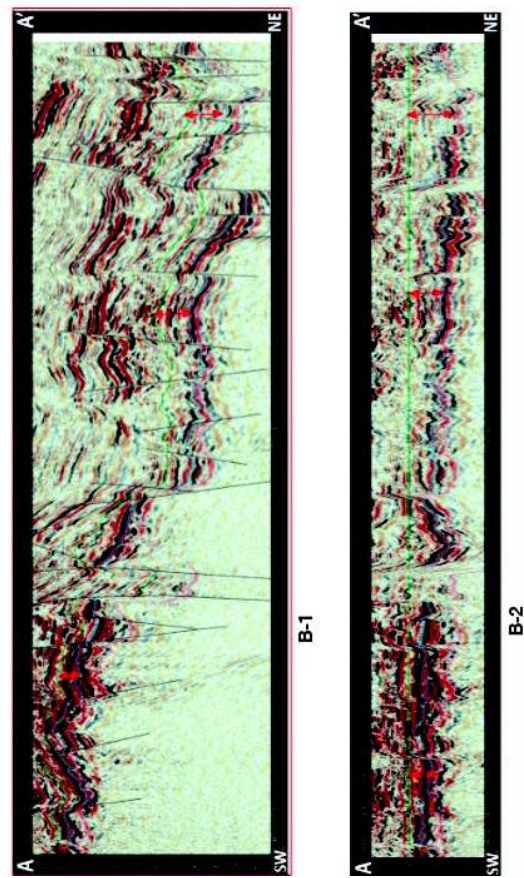

Fig. 5: (B-2) Section A-A'flatten at Kopili formation top 
north to south and from basin side to basin margin in the entire basin. The Shale dominated lower Kopili unit is present throughout the study area with minor thickness variation. The upper Kopili unit thickness variation is large from north to south and from west to east. In west and south western basin margin area, total upper Kopili unit is missing, even at few places lower part of Kopili unit is also eroded (Fig. 5(B-1) and 5(B-2)).

The sea transgression resulted more accommodation space towards basinal side and resulted more pach thickness with a prominent fining upward sequence in the late Eocene period (lower Kopili). This shale dominated lower Kopili unit is present throughout the study area. The later part of Kopili deposition witnessed regression of sea from basin margin and a coarsening upward sequence in the basinal side makes poor impedance contrast from overlying Barail sands. Probably this might have taken place due to uplifting of the south western part of the basin, where uplifted block had witnessed sub areal erosion. The regression of sea exposed much of the basin margin part to sub areal erosion, due to that the effective thickness of Kopili is very less in west and south west part. The effective thickness of Kopili pach is more in north perhaps due to slight tilting of the basin towards north east (Fig. 5(B-1) and 5(B-2)).

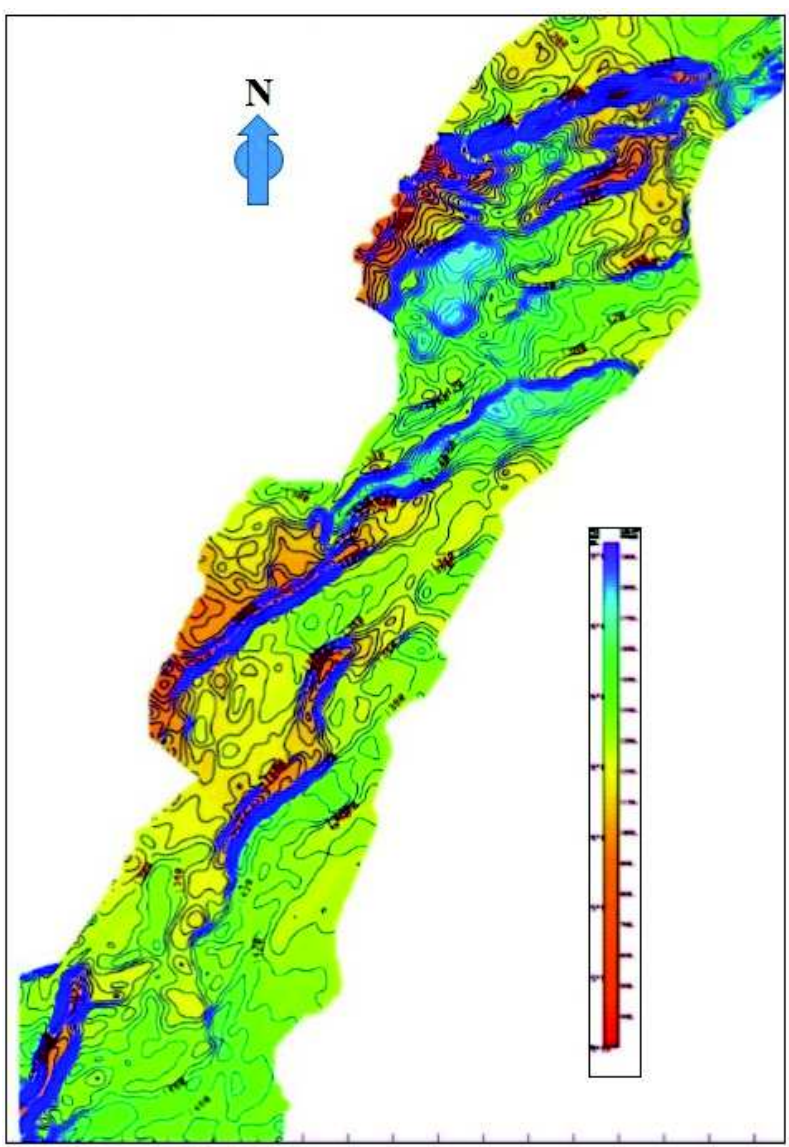

Fig. 5: (C) Isochronopach map between Basement top to Tipam top The tectonic disturbances were nominal. Faults
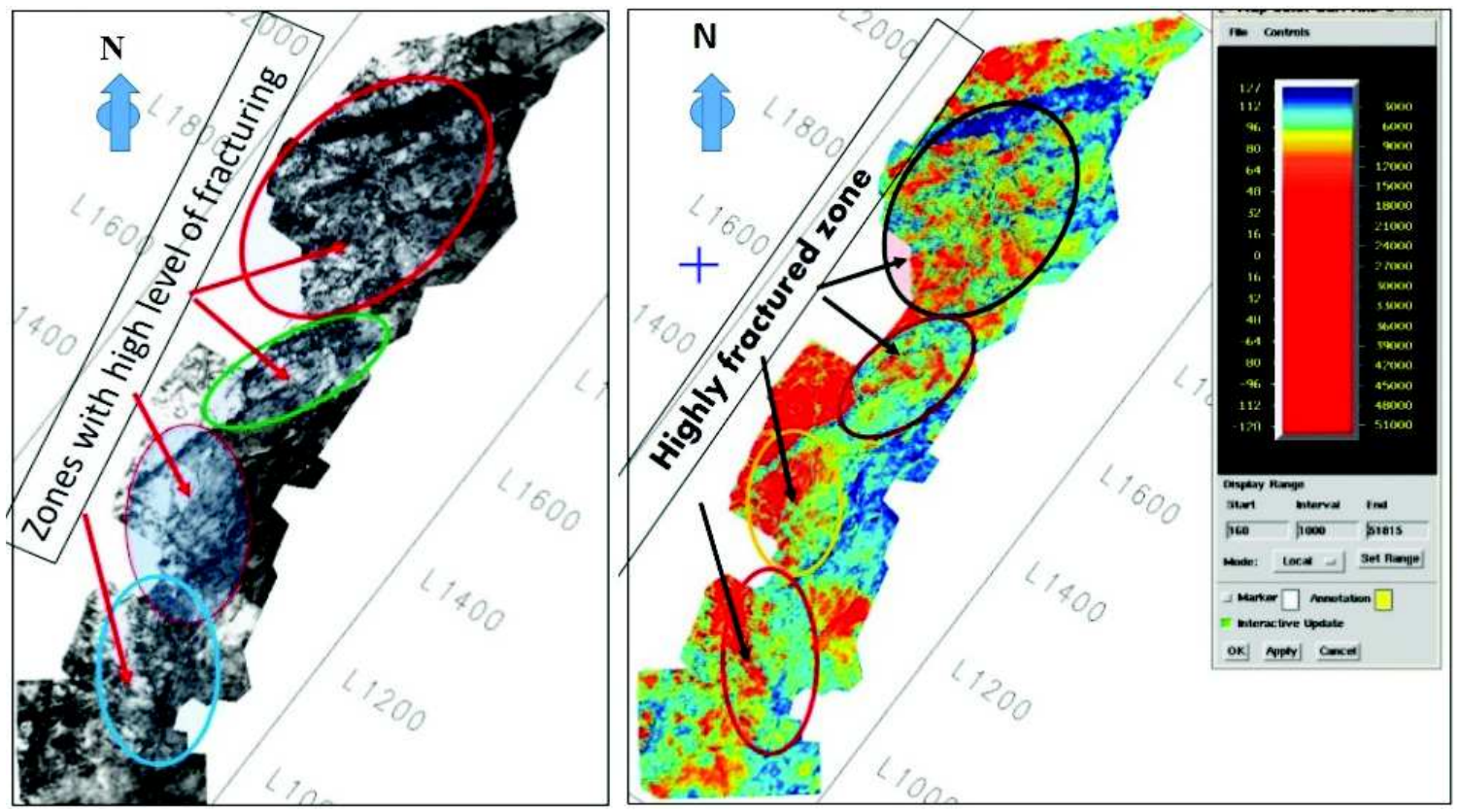

Fig. 5: (D) Coherence attribute on the top of Basement. Encircled areas are highly faulted 


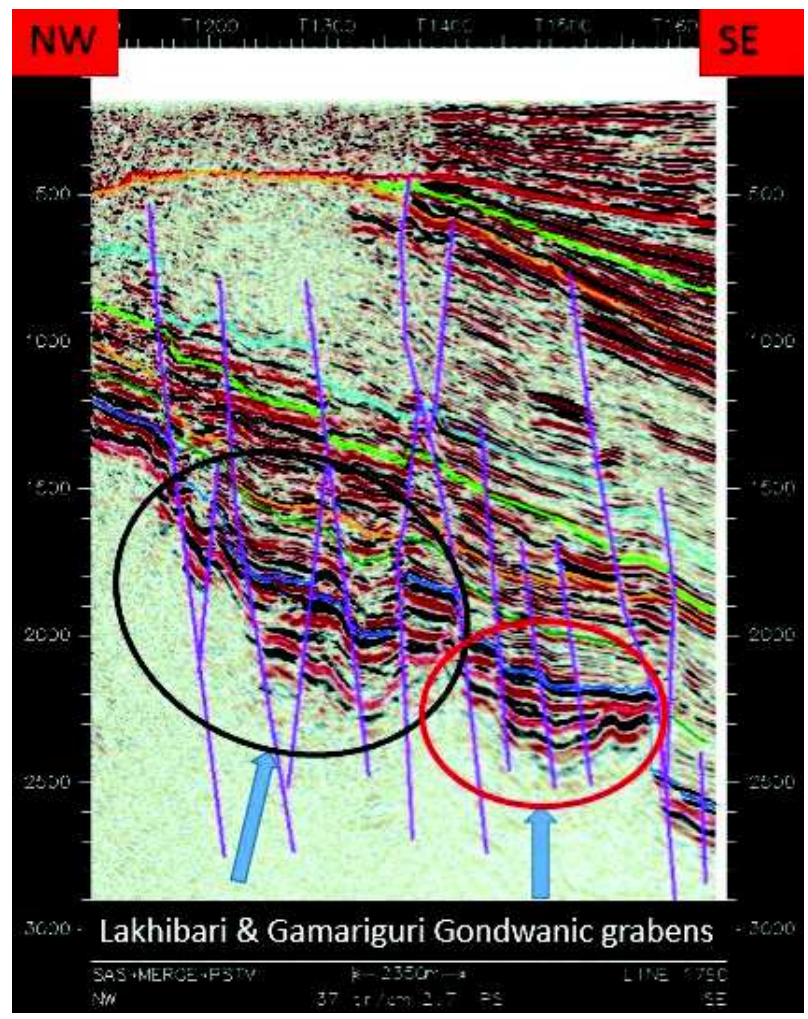

Fig. 6: (A) Seismic section passing through Lakhibari and Gamariguri area in the dip direction from north west to south east. Encircled areas are Gondwanic grabens filled with lower and upper unit of gondwanic sediments

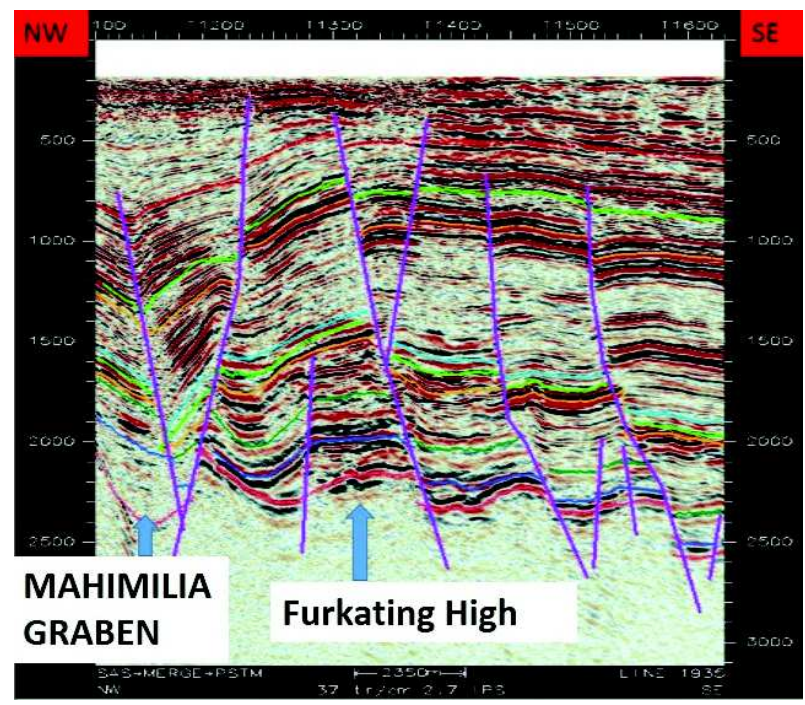

Fig. 6: (C) Seismic section passing through Furkating High with thick Gondwanic sediments

created during the rifting phase were still active. The sedimentation in the basin during deposition of Kopili formation, created a new set adjustment faults.

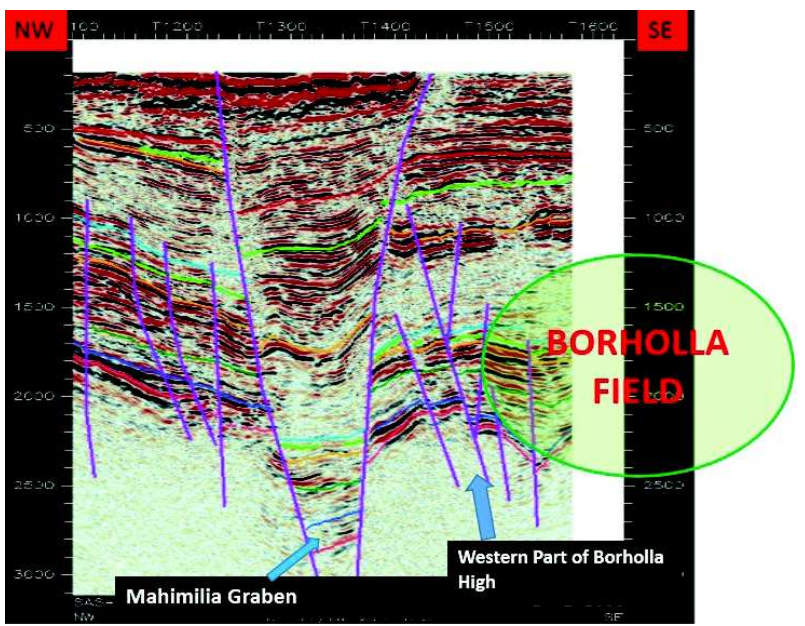

Fig. 6: (B) Seismic section passing through Mahimilia graben and Borholla area in the dip direction

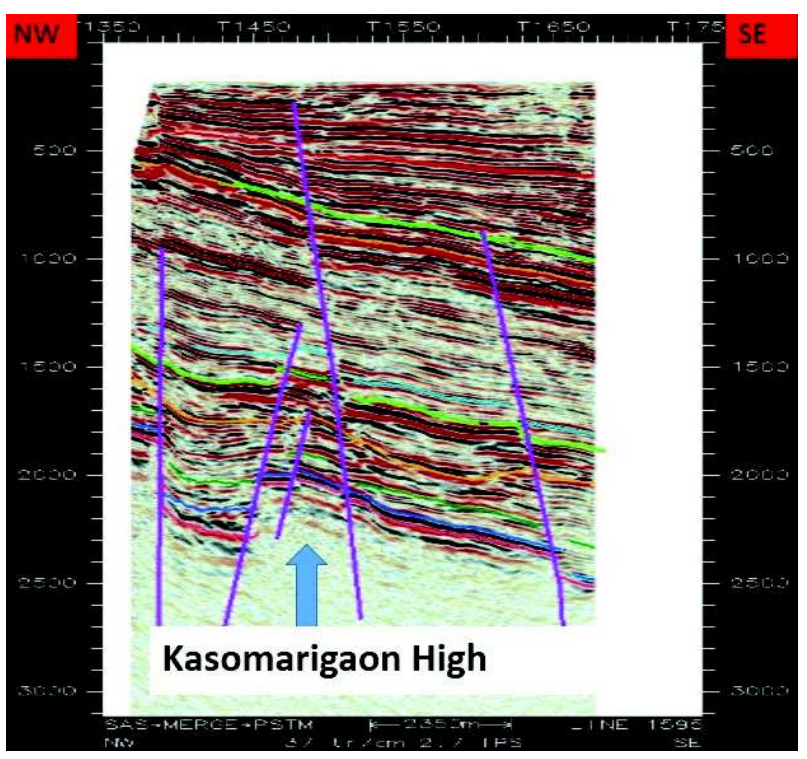

Fig. 6: (D) Seismic section passing through Kasomarigaon High at the basement level

The iso-chronopach map between Basement top to Tipam top (Fig. 5(C)), represents the overburden thickness over the basement at the end of Tipam. The pach thickness vividly shows accentuated lows and highs bounded by many longitudinal faults in the entire basin. It seems that most of the adjustment faults originated during the deposition of Paleogene sequences might have taken large throw during the late Miocene period due to younger tectonics. This younger tectonics has created large number of fractures in the basement in the basin margin, where sediment thickness over the basement were less. While in the basinal side, poor fracture density is 


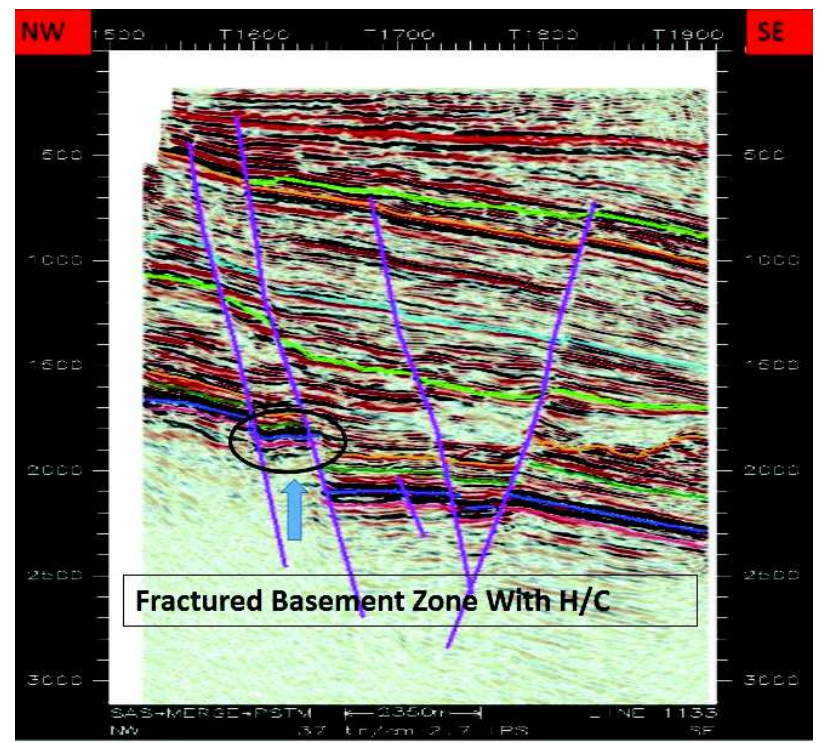

Fig. 6: (E) Seismic section passing through west of Khoraghat areawhich produced hydrocarbon from fractured Basement

anticipated in the basement, as stress absorbing sedimentary column is thicker over it.

\section{Impact of the Evolution of the Fore Deep Basin on the Basement}

The tectonic history of the South Assam shelf is very complex from north to south and from west to east. The two compressional forces, northern compression in the north south direction due to collision of Indian Plate with Eurasian Plate and eastern compression due to collision of Indian Plate with Burmese Plate have different effects on the orientation of major structures present in the area. The northern compression is effective from earlier time than the eastern compression and its influence is more in the northern part than the southern and has gentler effect in orienting the structures in east west direction from basement top to younger Formation i.e Girujan. The eastern compression is more effective after post Oligocene/early Miocene periods and has stronger influence in orientation of structures in north south direction and generation of strike slip components along younger faults.

The Gondwanic grabens due NE to SW and $\mathrm{N}-\mathrm{S}$ direction in the basin margin were peneplained before start of Tertiary sedimentations. Faults generated during the rifting phase of pre-Mesozoic period to bind Gondwanic graben became dormant till the middle Eocene period due to tilting of basin in south east direction. The younger tectonics of post Miocene/ Pliocene period due to eastern compression raised Borholla - Mekrong area as a structural high and adjacent western block of Gondwanic graben part down wrapped in to a deep low, which caused the formation of Mahimilia graben in ENE to WSW direction. Rising of Borholla structure in PlioPleistocene period in closed proximity to the Naga Schuppen Thrust created tremendous volume of fracturing in the basement due to eastern compression. Later on these Basement fractures were charged during the migration of Hydrocarbon, while down wrapping of Mahimilia graben at the same time obstructed the further migration of Hydrocarbon in the North West direction for deeper plays. Fig. 6(B) shows the section passing through Mahimilia Graben and western part of Borholla. The rising Borholla Champang block word close to the source within schuppen belt and bounded by a major graben like Mahimilia in its west, was charged in its fractured Basement and this might be the reason of great success in the Basement exploration in Borholla field.

Time relief maps on Basement top (Fig. 2(A)), on Sylhet top (Fig. 3(A)) and Kopili top (Fig. 4(A)) show very good structurization in the Furkating, and Lakhibari area in a linear ridge like pattern bounded by lows on either side. On this Furkating ridge, which is oriented in the north east to south west, several wells were drilled (Fig. 6(C). In these wells, although hydrocarbon shows were present, but there was no commercial success. The seismic attributes like edge detect on the Basement top (Fig. 2(B)), coherence attribute (Fig. 5(D)) and RMS amplitude attribute within weathered Basement (Fig. 5(E)) clearly represent severe fracturing associated to major faults. The younger eastern compressional tectonics has highly fractured the area including the top seal also, which might be a reason of poor and breached entrapment of hydrocarbon in the fractured basement and overlying Sylhet Formation in this corridor.

The seismic section passing through Gondwanic graben in the east Lakhibari area (Fig. 6(A)) shows the large number of faults at the basement level in comparison to its basinal side. Most of these normal faults were generated simultaneously during the evolution of horst \& graben sequences during the rifting phase of Indian Plate in early Mesozoic era. 


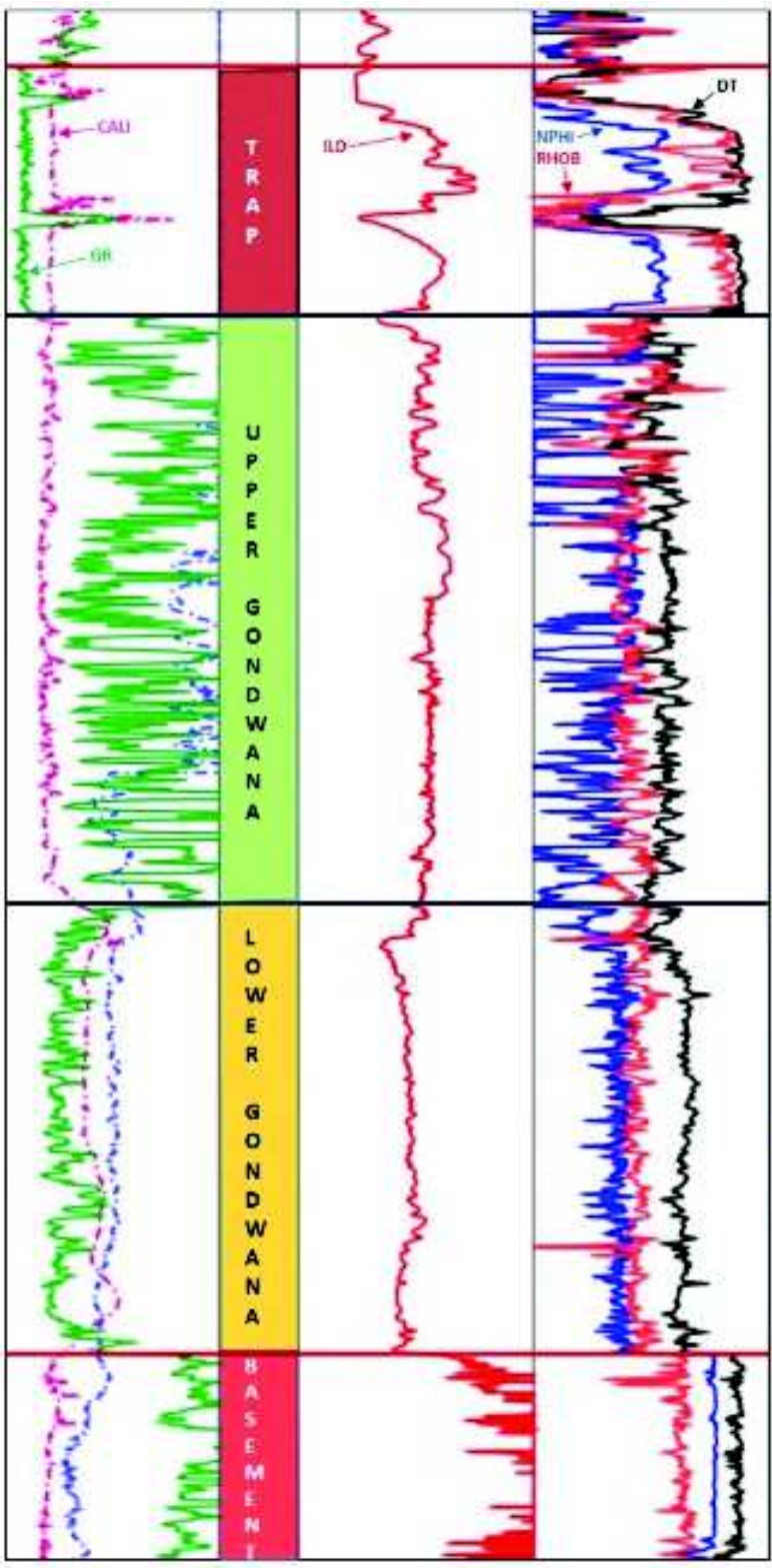

- Shale-sand alternation

- Medium to coarse sands

- Pyrite present

- Black to greenish grey shales, carbonaceous

- Cobbles, pebbles, rock fragments, clay, sandstone

- Fine to coarse sands with green quartz

- Grey to blackshales, carbonaceous

Fig. 7: Log motif of well A-1 drilled in Barpathar area having $337 \mathrm{~m}$ thickness of Gondwanic sediments overlying Basement. The lower part of gondwanic sediments arecoarser in nature, deposited in fluvial environment. The upper part of gondwanic sediments are mostly shales with few intercalation of medium to coarse sands

Later on they were reactivated due to post Oligocene fore deep evolution tectonics. Though the basinal side is more close to the evolving Naga Thrust than the basin margin, faulting is more towards basin margin especially in the south western part, probably due to less overlying sedimentary column. The overlying huge sediment load towards the basinal side resisted the eastern compression of younger tectonics. On contrary, the lesser sediment thickness towards basin margin might have poor resistance to the severe eastern and gentler northern compressions. This ultimately led to severe faulting and fracturing in the basin margin part at deeper level in the basement.

The seismic section depicted in Fig. 6(D) is passing through Kasomarigaon area, which is a prolific producer from Bokabil Formation, where hydrocarbon show were observed in the fractured Basement. The time relief map on the Basement top in Fig. 2(A) and time relief map on the Kopili top in Fig. 4(A) represent 
a Basement level promontory, bounded by lows on either side, followed by a ridge at the Sylhet and Kopili top level. The area has witnessed stress at the Basement level during rifting phase of the Gondwanic graben, followed by severe eastern compression after post-Miocene period. During the post-Miocene period, younger tectonics reactivated most of the older faults and resulted in high level of fracturing in the basement. The possibility of finding hydrocarbon in the Basement is high in this area.

The seismic section passing through Khoraghat area as depicted in Fig. 6(E) where commercial success was found in the fractured basement, shows the position of hanging wall block lying between two synthetic faults hading towards east. The block between these two synthetic faults has under gone severe deep level fracturing due to younger tectonics. Its western side foot wall block is a monoclinal rising part of Mikir Massif towards west and south west. A prominent north east to south west trending low, which is merging towards the major low below the eastern Naga Thrust in the east of Uriamghat separates this block with Khoraghat main field. This low is quite younger and during the late Oligocene period it was a high. The Barail Formation is highly eroded over here andthe Bokabil sediments are thicker and well stratified. The younger eastern compression raised the main Khoraghat Block upward against the west hading fault, while its western part got wrapped down in to a deep low. This low has a major role in migration of hydrocarbon to adjacent available structures from fractured Basement to younger formation i.e., the upper Bokabil.

\section{Conclusions}

The fractured Basement reservoir is very unconventional in nature.As the South Assam Shelf basin has witnessed severe tectonic activities in different phases, this poly-tectonic phases of basin evolution have created very complex fault and fracture networkwithin the Basement. At places where high fracture density is available in the

\section{Reference}

Das K C, Sarma V S B and Ayyadurai M (2004) Gondwana sediments: A promising Hydrocarbon exploration target in Assam Shelf, 5th international conference \& Exposition weathered Basement (for example in Furkating and Lakhibari area), the top and lateral seal are also fractured due to younger tectonics, may be the only explanation for absence of hydrocarbon in this region. Another example of absence of hydrocarbon in fractured Basement in west \& North West of Borholla area, structurally which is at par with adjoining Borholla field in the east at Basement level may be devoid of charging due to presence of a major low like Mahimilia obstructing the migration pathway. In western Basin margin, many structures have been drilled in west of Uriumghat with no shows of hydrocarbon in spite of presence of top and lateral seal along with fractured reservoir at the Basement level. This might be due to leaky nature of the major faults in the area, which are extending up to the surface.

\section{Way-forward for Basement Exploration}

- The basement locales should have better structural disposition with appreciable amount of over burden thickness (>2000m).

- The fracture density should be high.

- Robust entrapment condition should prevail i.e. top and lateral seal should be intact and unaffected by younger tectonic disturbances.

- $\quad$ Basement upliftment during younger period is to be focussed for Basement exploration in this area.

- Basement high along eastern margin seems to be more lucrative and less risk prone from hydrocarbon exploration point of view.

\section{Acknowledgement}

Authors are highly indebted to Director (exploration), ONGC for his permission to publish this paper. Authors highly acknowledge to Shri C Mahapatra ED, Basin Manager, Assam \& Assam Arakan Basin, Jorhat for his support and motivation in preparing this paper. Authors also acknowledge to Shri Pawan Kumar GM, Block Manager, SAS block for his continuous support and guidance in writing this paper.

on Petroleum Geophysics, Hyderabad 468-472

Jain Mukesh, Das Prabal Shankar et al. (2010) Structural

Framework and deep marine depositional environments of Miocene- Pleistocene sequence in western offshore 
Myanmar, 8th international conference \& Exposition on Petroleum Geophysics, Hyderabad 58-65

Reddy G V, Saha Trishna et al., Analysis of Kalyanpur field discovery in low resistivity silty reservoir in Dhanasiri valley, A \& AA basin, Assam - A Case study, 7th international conference \& Exposition on Petroleum Geophysics, Hyderabad 2008, 170-175
Wandrey C J, Sylhet-Kopili/Barail-Tipam, Composite Total Petroleum System, Assam Geologic Province, India, U.S. Geological Survey Bulletin 2208-D. 